\title{
Geology, landscape and human interactions: Examples from the Isle of Wight
}

\author{
K. A. Booth ${ }^{1}$, J. Brayson ${ }^{1}$ \\ ${ }^{1}$ British Geological Survey, Keyworth, Nottingham, NG12 5GG, UK.
}

\begin{abstract}
:
The British Geological Survey has recently re-mapped the Isle of Wight at a scale of 1:10,000. This has added to a wealth of geological research already published. Within this paper, we highlight the importance of geology to the heritage of the Isle of Wight and its impacts on everyday life. There is a growing cultural awareness of the variety of landscapes and resources, the geology that underpins them, and the need to manage and understand them in a sensitive and sustainable way. 'Geodiversity', which collectively embraces these themes, is defined as "...the natural range (diversity) of geological (rocks, minerals, fossils), geomorphological (land form, processes) and soil features..." (Gray, 2004). This paper will focus on the geomorphological features; that is, the link between geology, the landscape it influences, and the human interactions with it. Examples from the Isle of Wight of the influences of geology on landscape include the landslides at Ventnor; geotourism at The Needles, Alum Bay and various dinosaur sites; and the artificial landscapes resulting from resource extraction. The geological issues and examples that we have used are some of the most applicable to everyday life, and therefore ones that many people will be able to relate to, such as geohazards (e.g. landslides), water supply, economic value (e.g. quarrying) and tourism. The paper is aimed at the non-specialist and students but also may provide a contextual element to professionals.
\end{abstract}

Keywords: Isle of Wight; geological mapping; geological landscape interpretation; geodiversity; geotourism; human interaction; mineral extraction.

\section{Introduction}

Geology and geodiversity have received more interest in recent years particularly with the focus on climate change and impacts on our environment. Many Local Authorities are now publishing Local Geodiversity Action Plans (Burek and Potter, 2006) and DEFRA has provided various policies and guidance, e.g. Aggregate Levy Sustainability Fund, to reduce the impact of activities such as aggregate extraction (Defra, 2006). The value of outreach for both geology and geodiversity have been comprehensively reviewed in Anderson and Brown (2010), which concentrates on the Quaternary aspect of geology but their reasoning and assumptions can readily apply to all areas of geology. The method of outreach and communication is important and depends upon the target audience. Good communication will lead to better understanding of the geological environment, its implications and consequences. This paper draws on the increased scientific knowledge gained from detailed new mapping of the Isle of Wight and helps to highlight the importance of continued scientific research as well as raise awareness of environmental issues and sensitivity. This case study of the Isle of Wight can easily be applied across a variety of other regions.

\subsection{Background}

The first geological survey of the Isle of Wight was carried out by the British Geological Survey (BGS) (then named the Ordnance Geological Survey) and published in 1856 (British Geological Survey, 
1856) on the one-inch scale. The island was resurveyed in 1886-87 on the six-inch scale and reprinted a number of times to incorporate minor ammendments. The first 1:50,000 scale map of the Island was published by BGS in 1976 (British Geological Survey, 1976). Since those first surveys, a wealth of geological research has been undertaken and published covering a wide range of subjects from formation level descriptions (e.g. Insole et al., 1998) to the discovery of flint arrow heads that provide evidence of human occupation some 365 thousand years ago (Wenban-Smith et al., 2009). Over the past 3 years the BGS has completed a new detailed geological survey of the Isle of Wight, incorporating up-to-date knowledge of the stratigraphy, e.g. the modern chalk nomenclature, and new airborne geophysical data. A team of geologists has mapped, logged and sampled across the whole island, collecting a huge amount of scientific data and recording their observations at a scale of 1:10,000. This data will lead to new updated, more detailed geological maps. In this paper we will explore how the new geological map can be interpreted to reveal the rich Geodiversity of one of Britain's most popular islands. The island also boasts a stunning array of habitats for flora and fauna - for example the Chalk Downlands, and several areas classified as Areas of Outstanding Natural Beauty (AONB). These habitats are influenced by the underlying geology and it is raising the awareness of this that is essential to recognising its value and preserving these fragile environments.

The Isle of Wight is primarily a rural island with a large percentage of land use devoted to agriculture. The Digital Terrain Model (DTM) image (Fig. 1) shows the landscape features of the island.

The distinct shape and topography of the island is controlled by the dominant east-west trending Chalk Downlands. This elevated ridge creates a spine across the island and is formed by intensely hardened, folded and faulted chalk rocks. To the north of this east-west spinal structure, Palaeogene deposits, overlain by sporadic fluviatile and marine deposits, form gently sloping topography. The southern Chalk Downlands, isolated from the spinal folded feature, provide the greatest elevations on the island rising up to 235 metres OD on St Boniface Down. Separating these two areas of Chalk Downlands is an area of gently-undulating dissected topography, underlain by Lower Cretaceous rocks and patchy Pleistocene and Holocene deposits that relate to the present-day fluvial systems. The major rivers consist of the eastern and western Yar and the Medina rivers. These dissect the prominent chalk ridge as they flow northwards, taking advantage of weaknesses, such as faults, in the bedrock.

The major towns of the island are primarily situated in the north and east. The administrative municipality of Newport lies in the centre of the island, whilst other towns, such as Sandown, Shanklin and Ryde became extensively developed during Victorian times as popular tourist destinations. The island's main ports have been situated in locations that take advantage of the natural harbours and embayments - Cowes, Freshwater, Yarmouth and Bembridge.

Lying just a few miles off the south coast of England, split from the mainland by the Solent, the island has a significant geological story to tell.

\section{Landscape Domains}

This paper identifies the different landscape domains present on the island and examines the geology that underpins them (Fig. 2). These domains comprise the southern coastal plains and central low-lying Lower Cretaceous Wolds (Domain 1), the Chalk Downlands and foothills (Domain 
2), the Palaeogene landscapes of the north (Domain 3) and the Quaternary deposits (Fig. 3) that include the present day coastal areas and tidal flats of the northern coastline, and the numerous river deposits (Domain 4). These landscape domain-geology interactions will be discussed in chronological order and a generalised stratigraphy is provided in Table 1.

\subsection{Domain 1 - The Lower Cretaceous Wolds}

The majority of the central part of the island is characterised by the Lower Cretaceous Wolds. Landscapes of this domain are defined by low-lying, gently-undulating topography dominated by arable farmland interspersed with some pasture. The flat coastal plain around Brighstone and Chale Green gives way to gently undulating topography inland to Godshill, Newchurch and Shanklin. The area consists of small river valleys and low-lying poorly-drained areas that provide conditions preferable for peat formation. The undulating topography is formed by harder layers of sandstones, more resistant to weathering, with the valleys following lines of weakness such as joints, fractures or faults in the underlying rocks. These features are most obvious where they intersect the coast creating the often deep, steep-sided, and unstable 'chines' (gorges).

The oldest rocks (Wealden Group c. $140-125 \mathrm{Ma}$ ) on the island are seen where the Cretaceous Wolds meet the sea at Brighstone Bay on the south coast and at Sandown in the east. The cliffs that these rocks form are commonly unstable and often subject to landsliding because they comprise an alternating sequence of mudstone and sandstone layers. They represent deposition in an alluvial plain / river channel environment (Insole and Hutt, 1994), sometimes by flood waters, interspersed by quiet periods indicated by the presence of plant debris, teeth, scales and bones. The muds exposed at beach level can often reveal fossils - for example, a wave cut platform at Hanover Point on the south coast is revealed at low tide. This 'platform' is created by erosion by the sea stripping away softer mud or clay layers leaving the harder, more resistant sandstone layers. Such active erosion frequently reveals fossils and at Hanover Point, a favourite location for fossil hunters, dinosaur footprints are visible at low tide (Fig. 4). Examples of finds can be seen at the Dinosaur Isle Museum near Yaverland.

The overlying rocks, collectively known as the Lower Greensand Group, were laid down in shallow marine conditions 125 - 110 million years ago. Small pits can be found across the outcrop, most probably used for the extraction of building materials, with stone used locally in many buildings. The largest working pit currently extracting materials from the Ferruginous Sand Formation is the Bardon Vectis Quarry near Newport. Higher parts of this quarry also reveal chalk and overlying Quaternary sand and gravel deposits. The sandstone layers of these Lower Greensand deposits weather to produce soils that support heathland and gorse vegetation.

\subsection{Domain 2 - Chalk Downlands \& foothills}

\subsubsection{Chalk Downlands}

The island's interior and southern tip are dominated by the features typical of Chalk Downlands high rolling hills, steep southern scarp slopes and deeply incised valleys. The valleys are often dry, except in times of extreme rainfall, and the larger valleys contain clear chalk streams, ideal habitats for numerous species such as trout, and therefore provide excellent fishing. The negative 
topographical features we see today (the valleys, cols, saddles) have formed as a result of locally enhanced rates of erosion either along zones of weakness such as faults, or where there are dipping strata and softer rock layers.

Layers of hard chalk are interspersed with soft chalk and marl bands that weather at a greater rate and create an alternating prominent and weathered sequence. Numerous old pits and quarries can be seen within this landscape. These were frequently used to provide lime for adjacent farmland or materials, especially flints, for building. The buildings of a village can often provide a window into the local geology. For example, many buildings in Brighstone and Shorewell contain locally quarried flint and chalk.

The highest topography on the Isle of Wight occurs in the Chalk Downlands. These broad expanses of gently rolling hilltops have provided important lookout points in the past and continue to provide stunning views across the whole island and towards the mainland. A number have monuments or follies built upon them e.g. the tower on St Catherine's Down; the memorial to Sir Robert Worsley on Appuldurcombe Down; and the monument to Lord Tennyson atop of Tennyson Down.

Carisbrooke Castle is located on the site of a Roman fort and sits on a ridge of chalk at 125 metres OD. The hilltops are also important in terms of navigation and defence; the Sea Mark on Ashey Down was built in 1735 and was an important site for Navy communication using semaphore. There are examples of defence structures from Victorian times (such as the Needles Old Battery and Bembridge Fort) through to the more recent defences on Tennyson Down and Culver Battery (built 1904-1906) (Rushton, 2005). The former artillery battery on the Needles Headland was even used as a test site for rocket launches in the 1950s and 1960s.

The Chalk Downlands meet the sea at Compton Bay and the Needles in the west, and at Culver Cliff in the east. Here coastal erosion plays an important part in creating this landscape. The Needles, a series of sea-stacks formed from chalk jutting out into the English Channel, is one of the most famous landmarks on the island, in Britain and perhaps the world. A particularly tall stack, known as Cleopatra's Needle or Lot's Wife once stood between the first and second present day stacks but fell in 1764 . This and the presence on early $17^{\text {th }}$ Century charts of a cluster of 14 narrow columns of chalk north of the promontory are the probable source of the name 'The Needles'. Because of their prominent position, they have been eroded by winds and waves over time. Erosion by the sea has created arches in the chalk; when the arches became too weak, these collapsed leaving only the stacks we see today. Eventually these too will fall. In fact the entire south coast of the island was once much further to the south and has been eroded during the Quaternary period by marine processes, which still continue to the present day. Evidence of this erosion and cliff-retreat can be seen all along the coast in the form of rock falls, landslides and mud flows.

\subsubsection{The foothills of the Chalk scarp (Gault \& Upper Greensand)}

The lower foothills of the main Chalk escarpment trending east-west across the island, are formed by the Upper Greensand Formation underlain by the Gault Formation. The Gault Formation forms a narrow outcrop of clays from the coast at Compton Chine in the west, inland past Shorewell, Chillerton, Arreton, to the beach below Culver Cliff in the east. Typically it is composed of dark fossiliferous silty clays with some sand units. Low angle slopes are associated with the Gault Formation. Clays at surface are unstable above a certain slope angle (and influenced by the groundwater level) and cannot maintain slopes greater than approximately $20-30^{\circ}$ (this decreases to 
c. $10-15^{\circ}$ for previously failed slopes) (Forster et al., 1994). This gives rise to a landscape which is of low relief.

In many areas these clays act as a barrier to water flow and, where at depth beneath other units, cause increased pore water pressures and create planes of weakness. These factors cause instability leading to landslides, especially along the south coast. For this reason the Gault is known locally as the 'blue slipper'. The boundary between the Gault and overlying Upper Greensand is subject to abundant landsliding especially around Ventnor, St Catherine's Hill and Appuldurcombe.

High sandstone cliffs are seen around St Catherine's Hill and Appuldurcombe as well as along the coast between Luccombe and Blackgang Chine. These Upper Greensand Formation rocks contain prominent, very hard, large, nodular blocks of chert near the top of the formation that forms an escarpment more resistant to weathering.

A notable indication of instability is the hummocky terrain that is often caused by slides and slumps, in addition, there are often patches of water-logged ground, notable by the reeds and bog grasses that grow there. Occasionally a large boulder of the Upper Greensand formation is found lower down on the slopes, another indication of instability and evidence that the rocks are liable to toppling from the cliffs above.

Evidence of the instability of the Gault can be seen on slopes just above the road to Sibdown Farm and on the northern slopes of Appuldurcombe Down.

On the coast, evidence of this instability is abundant. Apart from the numerous rock-falls and clay slides along the beaches, there is also evidence on the cliff-tops. For example, near Blackgang Chine houses have fallen and only derelict remains are left, and roads come to an abrupt halt where once they would have been some distance from the cliff-edge. These inland and coastal examples, although both caused by landsliding and instability, are actually from two separate causes. The inland landslides developed some 10,000 years ago during the Devensian period when periglacial conditions would have favoured erosion and instability. Although spring seepage along the GaultUpper Greensand boundary is common, these landslides are essentially no longer active. However, the landslides along the coast are very much active and caused primarily by coastal erosion that is gradually eroding the landslide toe at the base of the cliffs. There have been numerous studies of the cliff retreat in this area (e.g. Hutchinson et al., 1981). At Blackgang Chine, the rate of erosion, although variable and sporadic, is in the order of $0.5 \mathrm{~m} \mathrm{a}^{-1}$ (Leyland and Darby, 2008).

Remains of old brick pits are also commonly seen across the Gault outcrop denoting the historical importance of this resource. For example around Rookley an old pit is still visible where brickworks once stood and clay was extracted.

\subsection{Domain 3 - the Northern Landscape (Palaeogene)}

The character of the Northern Landscape is typically low-lying farmland and woodland. On the north coast the numerous harbours, the low clay cliffs, and creeks are fringed by woodland. Formal landscaped estates, such as Osbourne House, dominate parts of the coastline, whilst Victorian seaside settlements are concentrated on others. 
The rocks underlying this northern landscape were deposited during the Palaeogene era (65 - 23 million years ago) and comprise a layered succession of muds, sands, clays, silts, limestones and pebble beds. Further detail on the Palaeogene strata can be found in Edwards and Freshney (1987) and Insole and Daley (1985). Palaeogene sand and sandstones give rise to dry sandy soils that support plants such as gorse and heather - heath land on these types of rocks is common. The heavier clay-rich layers support a different habitat, often wet and water-logged in the winter and dry and parched in the summer months. Small copses and woodland commonly exist on clay-rich soils. As discussed previously in section 3.2.2, clay slopes are only stable at relatively low angles and consequently, the topography is of low relief.

The multi-coloured striped cliffs at Alum Bay, a popular tourist spot where visitors can use the coloured sands (principally from the Bracklesham Group) to fill patterned glassware, are created by steeply-dipping Palaeogene strata giving an almost vertical-stripe appearance along the bay. These inter-bedded, often mottled, sands and clays are part of the Lambeth Group, London Clay Formation and Bracklesham Group and were deposited in marine-estuarine fluvial environments. The mottling and colour changes are due in part to pedogenic (soil) processes in a humid environment (Buurman, 1980) and indicate fluctuations in the water table. These conditions give the rocks their colours as the iron content within them is either oxidised during periods of sub-aerial weathering or reduced in ephemeral lagoons. The proportion of sand beds varies greatly, but at Alum Bay sands dominate. Elsewhere on the island these beds form a narrow outcrop just north of the Chalk Downlands. Alum, a double sulphate of aluminium and potassium was formerly manufactured from the pyriteous clays in the Palaeogene beds and gives its name to this famous beauty spot but was also produced at a works in Parkhurst Forest as early as 1579.

A large proportion of the northern part of the island consists of farmland, pasture and woodland or coppice. Tidal creeks and rivers dissect the stratigraphy. The low-lying, relatively flat areas around Bembridge and Brading are created by the flat expanse of the Bembridge Marls Member (calcareous clays).

The Palaeogene deposits have been and, in some cases, still are extracted for resources. The Bardon-Vectis Quarry near Newport is an active quarry producing valuable sand and gravel resources from both the Quaternary and Lower Cretaceous deposits. These raw materials are used for aggregate, concrete, and in the manufacture of other materials (Hopson and Farrant, 2009).

\subsection{Domain 4 - the Quaternary deposits}

Quaternary deposits are widespread across the island in the form of tracts of river deposits, coastal and estuarine deposits and high-level gravels (see Fig. 3). Clay-with-flints deposits cap the Chalk Downlands. All these deposits are patchy in distribution but do affect the shape of the landscape and the habitats that occur there. The landscape associated with these deposits is often relatively flat and in the case of river terraces, form a stepped profile within a river valley. River terraces are deposits that create stepped bench-like features adjacent to rivers due to the down-cutting of the river profile. 
During the Quaternary Period (the last 2.6 million years), the Isle of Wight lay beyond the limits of glaciations in Britain but it was subjected to numerous periods of periglacial and temperate climates. Active and dynamic landscapes prevailed during cold periods (periglacial climate) where freeze-thaw and frost shattering processes led to high sediment availability. Hillslope mobility would have been accentuated by solifluction, gelifluction and creep processes, especially during periods of seasonal melt of snow and active layer processes. Along with this abundance of available material, high stream discharge would have enabled the transportation of this material and ultimately the aggradation of river terrace gravels. An example of a high level terrace are the gravels found on St George's Down which consist of over 7 metres of gravel and sand at an elevation of 108 metres OD. This is the highest Quaternary fluvial gravel on the island (Gibbard and Preece, 1999; Hopson and Farrant, 2009). Evidence for severe frost-shattering in the surface of the chalk, and subsequent downslope mobilisation of material has been identified around Ventnor, as described by Preece, (2009).

During the climate transition from cold to warmer periods, sediment availability decreased but discharge remained relatively high. Erosion became more aggressive and, coupled with the longterm uplift of the region, rivers were able to incise downwards leading to the development of river terraces.

During temperate interglacial (warm) periods, rivers evolved in response to changes in sediment supply and flow rate. Floodplains were created and lateral erosion and deposition took place. These low-energy fluvial systems transported finer grained sediment loads and developed into meandering river systems. Sea-levels rose and deposited marine sediments at higher elevations, such as the raised beach deposits on the north coast. During the Ipswichian Interglacial (125 thousand years ago) the Isle of Wight was separated from the mainland when the Durlston Point - Needles ridge was breached by the sea (Bates and Briant, 2009).

\subsubsection{Clay-with flints}

Periglacial processes are also responsible for the erosion and reworking of the Palaeogene deposits. Some of this weathered material provided sediment for the rivers whilst the deposits capping the chalk were eroded and reworked with little transportation and are now forming the Clay-with-flint caps found on many of the chalk crests.

\subsubsection{River deposits}

The river patterns on the island are closely related to the type of underlying geology. The major rivers on the island include the Rivers Yar (East and West), and the River Medina and are associated with river terrace deposits, alluvial tracts and peat.

These deposits can vary greatly in content but often provide vital sand and gravel resources. These tracts along the banks of rivers are often used for animal pasture as they may be prone to flooding in extreme weather and become waterlogged for periods of the year. Houses and other structures built in these areas need to incorporate features designed for these specific conditions to best mitigate the risk of flood damage. 
The Chalk Downlands are well-drained with several clear chalk streams draining the major valleys, plus numerous dry valleys with no active drainage channels. Today, water in these valleys is able to percolate into the underlying permeable chalk rocks whereas when they were formed, permafrost conditions meant that water was unable to infiltrate and passed over the surface instead. Erosion of such valleys often occurs along lines of weakness such as faults or joints within the rocks. Spring lines reflect changes in the bedrock geology from a permeable rock e.g. chalk or sandstone, to an impermeable rock such as clay. The names of streams and villages can also indicate the underlying local geology. For example, the village name of Calbourne is derived from an Anglo-Saxon term meaning a stream usually flowing from a spring. This indicates that the local geology is therefore favourable for spring formation. The village of Calbourne is located close to the boundary between the Chalk (permeable) and the Palaeogene (less permeable) deposits, giving rise to springs. The valleys on the chalk are dry whereas the lower-lying clay-rich Palaeogene deposits hold water and streams are formed.

\subsubsection{Wetlands}

The River Medina at Cridmore, and northwards towards Newport, is associated with large stretches of peat. Brading Marshes are saltwater marshes just north of the steep chalk escarpment. Both are important habitats that support many species of flora and fauna but are becoming increasingly rare. The geology beneath these wetland areas is impermeable, e.g. clays that usually occupy flat lowlying areas. Water flow is inhibited promoting ideal conditions for stagnation, decaying plant material and the formation of peat. The marshes near Brading were originally created by tidal sediment deposition following the Holocene sea-level rise, and Brading Haven was situated at the mouth of the River Yar and formed a wide estuary. During Roman times, this seaway extended inland to the Brading Roman Villa. Since Roman times the area has been artificially managed and switched between a tidal inlet and an isolated freshwater marshland. On many occasions, the area has been cut-off by artificially engineered embankments only to be breached again, at a later date, by the sea forcing a return to tidal conditions. The area is currently owned and managed by the Royal Society for the Protection of Birds (RSPB) who have recently proposed that Brading Marshes should be returned to its natural state as a tidally flooded wetland. A similar situation can be found at Newtown National Nature Reserve (managed by the National Trust) where sea defences have been removed deliberately to enhance the site for many different species. It provides an important wintering ground for wildfowl and waders but also saline lagoons (on the site of old salt working) for sand shrimp and other specialist lagoon species.

Sediments at Bembridge were deposited in an estuarine environment, but are now found lying at c. 40 metres OD indicating a much higher relative sea-level in the past. Analysis of pollen from these sediments has found that they contain flora indicative of an interglacial period (Holyoak and Preece, 1983). The pollen record provides good evidence that the island was densely wooded until the early Bronze Age (c.4000 years ago), when widespread clearance and farming began (Jones and Keen, 1993). Bronze Age settlers tended to settle on lower ground and used the Chalk Downlands for arable crops and grazing land.

\subsubsection{Coastal areas}

The coastal areas and tidal flats of the northern coastline are constantly changing as sediments are deposited by tides and storms in some areas, whilst removed by erosion from others. The waters 
around the island are very dynamic with strong tides and currents, ideal for the many yachting events held in these waters. Tidal flats, providing important habitats, are most widespread on the more protected northern coast, near Newtown for example (see Section 3.4.3). These deposits are amongst the most recent on the island and are still actively forming today. The exposed southern coast is the most vulnerable to erosion with storm waves travelling across the Atlantic and battering the coast.

The management of coastal erosion varies from area to area as discussed in the Isle of Wight Shoreline Management Plan (2010). In many areas, coastal defences have been installed such as at Sandown and Shanklin, Ventor, Bembridge and Cowes. Whereas in other areas, such as Brighstone Bay, defences are not used and nature is allowed to take its course. Often, these decisions are controversial but the larger picture needs to be taken into consideration. If off-shore defences are used, this will alter the natural longshore drift and shifting of sediment, with possible consequential effects elsewhere.

\section{Human interaction with the geology of the island}

The interplay between humans and geology is much more complex than many people realise - many of the everyday things that we take for granted are underpinned by geology. By increasing awareness of the complex relationships between geology, landscape and the environment around us, the Isle of Wight's finite resources can be protected. In recognition of this, the Isle of Wight is currently being proposed as a potential Geopark similar to the English Riviera Global Geopark in Devon. For the purpose of this paper, we have divided the human interaction with geology on the Isle of Wight, into four main categories: Aquifers, Mineral Resources, Geo-Tourism and Geohazards. These categories are discussed in detail below.

\subsection{Aquifers}

Clean potable water is an essential utility for domestic, commercial and industrial uses on the island. Small volumes of water are obtained from rivers and reservoirs but the major source comes from groundwater aquifers. Although these aquifers are many metres below the surface, they are still fragile and susceptible to damage by pollution or over-abstraction. Geological mapping can potentially ascertain where aquifers can be exploited, their potential flow rates and also where they should be protected. Aquifers on the island provide up to $75 \%$ of the public water supply (IOW Council, 2001). The remaining $25 \%$ is taken from the mainland to the island via 2 pipelines laid by Southern Water in 2008 - these provide the population with drinking water especially during the summer when the island's population swells with visitors (during the 2009 seven week peak period alone there were 600,000 visits to the island - Isle of Wight Tourism Research Reports Visitor Statistics). A large number of abstractions are also made for irrigation, especially in the south of the island but most water for irrigation is drawn from surface waters which can be in short supply during the summer. Demand for water on the Isle of Wight is expected to increase by $15 \%$ in the next 25 years (Isle of Wight Water).

The main sources of groundwater on the island are the Chalk and Upper Greensand Formation of Domain 2 along with the Lower Greensand Formation of Domain 1. Water is also abstracted, on a 
local scale, from several minor aquifers predominantly in the northern part of the island (Domain 3). These aquifers exist in parts of the Hamstead and Osbourne Beds of the Palaeogene. Wealden Group deposits (of Domain 1 ) in the south contain minor aquifers but these can be mineralised and unpotable. These minor aquifers all have lower porosity (less water-holding capacity) than either the Chalk or the Greensand Formations.

Inadvertent pollution of an aquifer could render it unusable for thousands of years. Potential sources of groundwater pollution include prolonged use of chemical fertilizers and pesticides in farming practices, and chemical or fuel spillages. Infiltration potential depends upon numerous factors such as the composition of the soils and rocks at the surface and the level of the local water table. Pollutant pathways can be numerous, either taking advantage of weaknesses in the rocks (bedding, joints, fractures), or via contamination of river-water and subsequently infiltration into the ground.

Groundwater is also abstracted by both water companies and by landowners for their own use. Identifying these abstraction localities is dependent upon knowledge of the geology to identify suitable water-bearing rocks within the local stratigraphy. The search for water has to be controlled (usually by licence) as over-abstraction is potentially detrimental and could create a number of issues such as reduced river flows, reduction or cessation of flow from other abstraction boreholes, and the potential for saline intrusion. Although water is an abundant resource, if not properly managed, human activities can be detrimental to its preservation.

\subsection{Mineral Resources}

Mineral resources are an essential commodity that underpins infrastructure and materials in everyday life, from the sands gravels and limestones used in the construction of roads, the rocks used for building stones, to the chalk used as a raw material in cement manufacture and as lime for improving soil quality for food production. Mineral extraction sites are often seen as having a negative impact on the environment but companies have an obligation to restore sites once extraction is complete. Sites are frequently transformed into recreational lakes, nature reserves or areas for new housing - providing benefits to those that the extraction previously affected. Local mineral extraction also reduces the journey length needed to bring resources to the island, therefore reducing their carbon footprint. Geological mapping identifies areas of potential resource which not only allows extraction to continue but also benefits the Isle of Wight economy.

The Isle of Wight is self-sufficient in the majority of its mineral resource needs, however, it does import some crushed rock from the mainland which is used for road construction and in concrete and asphalt. The British Geological Survey's Britpits database records all active and ceased mineral extraction sites in the UK. Fig. 5 shows the distribution of these sites on the Isle of Wight in terms of working status, mineral extracted and end use.

Currently active sites are extracting limestone, chalk and sand and gravel. Approximately $50 \%$ of the required amount of sand and gravel is extracted on the island, the remainder being provided by local marine dredging operations.

In the past, a wider range of mineral resources were extracted from and utilised on the island and beyond. Bricks were produced for example, from the Gault Clay at Rookley and Bierley; and on a 
smaller scale from clays from the Hampstead Beds and the Quaternary 'brickearths' (notionally a wind-blown silt deposit) elsewhere. The brick making industry ceased on the island in the late 1950's (see the Isle of Wight Industrial Archaeological Society for more information). A small amount of poor quality coal and peat have also been extracted on a small, non commercial scale (Mc Evoy et al. 2002).

The extraction of chalk has evolved with the development of technology and increase in demand from small, local pits dotted across the Chalk Downlands to much larger scale operations. In 1999 approximately 40,000 tonnes of chalk were produced in the Isle of Wight. This came from 5 quarries within the Central Downs (Domain 2); $75 \%$ of this was used as constructional fill material, the rest for agricultural lime and industrial uses (McEvoy et al 2002).

Chalk (and the flints within it) have also been used as building stone in the past along with sandstones from the Upper Greensand Formation (Lott, 2010 (this volume)). Bembridge Limestone and other freshwater limestones (e.g. Quarr Stone as it is known locally) were extracted at Quarr and Binstead; this high quality building stone was mainly exported to the mainland. It has been used as building stone from Norman times onwards in numerous stately or public buildings such as the White Tower at the Tower of London (built c. 1110), Lewes Priory, East Sussex, the Keep of Canterbury Castle and other major ecclesiastical houses such as Christchurch Priory.

\subsection{Geo-Tourism}

The economy of the Isle of Wight is based on three main areas: agriculture and horticulture, light industry and tourism. With manufacturing in decline and agriculture and horticulture limited by space available, tourism has the greatest potential for future development. A significant proportion of the attractions for tourists are based on the island's geology. This 'Geotourism' not only includes the Needles, dinosaur footprints and the coloured sands of Alum Bay but also the landscape itself. As previously described in section 2 , the underlying geology dictates the shape and character of the landscape.

The Isle of Wight is rich in fossils and, in particular, dinosaur bones and footprints which are very popular with children and adults alike. Dinosaur Isle is a hugely popular visitor attraction and scientific resource which is operated by the Isle of Wight Council. This is a clear acknowledgement that geotourism is recognised as an important part of the tourist economy; it also features in the Isle of Wight Council's Tourism Development Plan (2005) - The 2020 Vision for Tourism which aims 'to maximise the wealth of... landscapes on the island in promoting to key markets'. It provides educational services to school groups and others, an identification service and also gives information to the council when a planning application may affect geological exposures. This education and protection are key to the ongoing survival of key geological features of the Isle of Wight.

Another example of successful geotourism is the establishment of The Needles Park, which draws many tourists to this far western point of the island. The geology, and the natural landscape that it creates, provides stunning vistas including the towering white chalk cliffs, the famous coloured sands of Alum Bay, the classic chalk sea stacks of the Needles. All these natural geological features provide the background and landscape for the Park; the high cliffs provide an ideal location for the chair lift, the sands provide the materials for the glass ornament souvenirs, the crazy golf effectively uses the Jurassic dinosaur theme and pleasure boat trips make further use of this wonderful scenery. This 
geology is discussed in more detail in sections 3.2 and 3.3 above. The coloured sands, sourced mainly from the Bracklesham Group, can be found in 21 different colours. The tradition of filling glass ornaments with layers of coloured sands dates back to Victorian times and was made famous when Queen Victoria was given some as a gift.

\subsection{Geo-Hazards}

Geohazards can have an enormous effect on everyday life as well as a large monetary cost. These effects are highlighted when a catastrophic event, such as a large landslide or rock fall destroys property or infrastructure, and has high-profile reporting in the news and media. Landsliding is the most important geohazard on the Isle Wight. There are c. 90 individual landslides documented on the Island (Foster, 2010) which vary greatly in order and magnitude, some causing minimal disturbance to everyday life whilst others cause more obvious problems with damage to homes and property and require detailed engineering solutions to mitigate any further damage. An example of landslide damage caused by coastal erosion is seen at Hanover Point car park (Fig. 6) where intermittent instability causes parts of the car park to collapse.

As previously discussed in section 3.2, the geology of the Isle of Wight comprises some units that are particularly susceptible to landsliding; this is exacerbated by the island's exposure to coastal erosion. The new geological mapping of the Isle of Wight allows us to analyse the conditions and rock types involved in current landslide areas and to apply this knowledge in other areas to predict where potential future problems might occur and mitigate this risk.

The landslides of the Undercliff (south eastern Isle of Wight) are the oldest of the landslides on the island (at least 28,000 years old). The landslides are thought to originally have been triggered by fluvial erosion of St Catherine's Deep possibly associated with the 'Solent River' or the 'Channel River' combined with marine erosion associated with a changing sea-level due to melting ice during interglacials. After the initial formation, the landslide complex would have reactivated during interglacial periods where sea-levels would rise. Although some remedial and preventative works are carried out on the landslides of the Undercliff (Hutchinson, 1991), mostly it is accepted that it is impossible to prevent further movement. The movement is caused by erosion of the landslide toe by the sea but also can be triggered by rainfall. Evidence of this movement can often be seen on the A3055 road which may eventually have to be rerouted inland (Hutchinson and Bromhead, 2002).

Landslide experts from the British Geological Survey mapped the extent of both coastal and inland landslides (Foster, 2010). However much work has also been done by universities, consultancies and individuals; it is this combined knowledge of the cause and movement of these landslides that will help authorities make important planning decisions in the future.

Dissolution is a common hazard in areas of carbonate bedrock, including the Chalk of the Isle of Wight. Water infiltration through pore spaces, jointing or other planes of weakness are subjected to dissolution of the calcium carbonate component, creating a void. Overlying deposits then collapse into this void over time producing 'solution hollows'. These features are usually found in or close to clay-rich deposits (relatively low permeability) overlying chalk (high permeability). Water run-off from the clay-rich deposits and infiltration into the chalk is concentrated in these zones causing dissolution of the chalk over time and ultimately potential collapse forming a solution hollow. 
The occurrence of these solution hollows is concentrated within 200 metres of cover deposit margins (McDowell et al 2008). Therefore, more detailed mapping results in better prediction of the areas at risk allowing developers to mitigate that risk; the recent survey has identified many solution features (dolines) across the chalk outcrop.

\section{Conclusions}

The geology and its detailed representation on a geological map provides essential scientific information that underpins our society and economy, and our ability to sustain our needs for the future. This geological knowledge is needed to be able to locate and exploit resources such as clean water, fuel and energy for homes and industries; to find engineering solutions for safe developments and mitigation of natural hazards; and to protect our environment, mitigate pollution, and find waste solutions. The Isle of Wight has many of these essential aspects and, although the island will not be subject to major resource extraction or industry, it is important to recognise what resources are available, their uses and controlled exploitation, and to have an understanding of the impacts. The resource need must be met by economically viable and sustainable extraction without damaging the landscape. Equally, the underlying chalk aquifer needs to be protected and we must ensure that water from wells and rivers is not over-abstracted or polluted. It takes many hundreds of years for rain-water to infiltrate and replenish the aquifer.

Engineering solutions are essential in parts of the island and large amounts of landslide remedial work have already been undertaken. This onshore work may also be complimented by offshore defences to slow the rates of coastal erosion. The island's economy also relies to a large extent on tourism which in turn is largely based upon the diverse and dramatic geology of the island. The understanding of this geological heritage is critical to the future preservation and development of the island.

\section{Acknowledgements}

The authors would like to thank Dr Jonathan Lee and Mark Woods for constructive advice and guidance, David Anderson for constructive comments on an earlier manuscript which have greatly improved the paper, Dr Claire Foster for advice on geohazards and Emma Crew for sourcing mineral resource data. Kathryn Booth and Joanna Brayson publish with the permission of the Executive Director of the British Geological Survey (NERC).

\section{References}

Anderson, D.E. and Brown, E.J. 2010. Perspectives on Quaternary outreach and aspirations for the future. Proceedings of the Geologists' Association, 121, 455-467.

Bates, M.R. and Briant, R.M. 2009. Quaternary sediments of the Sussex/Hampshire coastal corridor: a brief overview. In: Briant, R.M., Bates, M.R., Hosfield, R.T., Wenban-Smith, F.F. (Eds.), The 
Quaternary of the Solent Basin and West Sussex raised beaches; Field Guide. Quaternary Research Association, pp 21-41.

British Geological Survey. 1856. The Isle of Wight. One-inch Old Series, Sheet 10, England and Wales.

British Geological Survey. 1976. The Isle of Wight. 1:50,000, Special Sheet, England and Wales.

Burek, C., Potter, J., 2006. Local Geodiversity Action Plans-setting the context for geological conservation. English Nature Research Reports, No. 560.

Buurman, P. 1980. Palaeosols in the Reading Beds (Palaeocene) of Alum Bay, Isle of Wight, UK. Sedimentology, 27, pp 593-606.

Defra, 2006. Aggregates Levy Sustainability Fund in England 2002-2007. Defra, London. Edwards, R.A. and Freshney, E.C. 1987. Lithostratigraphical classification of the Hampshire Basin Palaeogene deposits. Tertiary Research, 8, 43-73.

Forster, A, Hobbs, P. R. N, Cripps, A. C, Entwisle, D. C, Fenwick, S. M. M, Raines, M. R, Hallam, J. R, Jones, L. D, Self, S. J, and Meakin, J. L. 1994. Engineering geology of the British rocks and soils: Gault clay. British Geological Survey Technical Report WN/94/31.

Foster, C. 2010. Distribution and nature of landsliding on the Isle of Wight. British Geological Survey Internal Report, IR/09/062. 14pp.

Gray, J.M, 2004: Geodiversity: valuing and conserving abiotic nature. John Wiley \& Sons, Ltd. ISBNs: 0-470-84895-2 (HB); 0-470-84896-0 (PB)

Gibbard, P.L. and Preece, R.C. 1999. Southern England. In: Bowen, D.Q (ed.) A revised correlation of the Quaternary deposits in the British Isles. Geological Society Special Report no.23, pp. 59-65.

Holyoak, DT and Preece, RC (1983). Evidence of a high Middle Pleistocene sea level from estuarine deposits at Bembridge, Isle of Wight, England. Proceedings of the Geologists' Association, 94, 231244.

Hopson, PM, and Farrant, A.R. 2009. The St George's Down - The Plateau Gravel - a Preliminary Discussion. In: Briant, RM, Bates, MR, Hosfield, RT and Wenban-Smith, FF. (eds) The Quaternary of the Solent Basin and West Sussex raised beaches; Field Guide. Quaternary Research Association. pp 21-41.

Hutchinson, J.N. and Bromhead, E.N. 2002. Isle of Wight Landslides. In McInnes, R.G. and Jakeways, J. (eds), Instability Planning and Management. Proceedings of the International Conference. Ventnor, Isle of Wight, UK. 20-23rd May 2002. Thomas Telford.

Hutchinson, J.N. 1991. The landslides forming the South Wight Undercliff. In Chandler, R, J. (eds). Slope Stability Engineering: Developments and Applications. Proceedings of the International Conference on Slope Stability Organized by the Institution of Civil Engineers and held on the Isle of Wight on 15-18 April 1991 (ed. R.J. Chandler), Thomas Telford, London, pp. 157-68. 
Hutchinson J.N., Chandler, M.P. and Bromhead, E.N. 1981. Cliff recession on the Isle of Wight SW Coast, Proceedings of the 10th International Conference on Soil Mechanics and Foundation Engineering, Stockholm (1981), pp. 429-434.

Insole, A.N., Daley, B. and Gale, A., 1998. The Isle of Wight, Geologists' Association Guide No.60. $132 \mathrm{pp}$.

Insole, A.N, and Hutt, S. 1994. Palaeoecology of the dinosaurs of the Wessex Formation (Wealden Group, Early Cretaceous), Isle of Wight, southern England. Zoological Journal of the Linnean Society, 112, pp135-150.

Insole, A.N. and Daley, B., 1985. A revision of the lithostratigraphical nomenclature of the Late Eocene and Early Oligiocene strata of the Hampshire Basin, southern England. Tertiary Research, 7, $67-100$.

Isle of Wight Coast Shoreline Management Plan 2010:

http://www.coastalwight.gov.uk/smp/index.htm

Isle of Wight Council, Directorate of Environment Studies. Contaminated Land Inspection Strategy Oct 2001.

Isle of Wight Council, Tourism Development Plan Oct 2005:

http://www.iwight.com/council/documents/docFiles/2732006 7 tourismdevelopmentplan.pdf

Isle of Wight Tourism Research Reports: http://www.islandbreaks.co.uk/site/isle-of-wight-tourismresearch-reports

Isle of Wight Water:

http://www.southernwater.co.uk/Environment/inYourArea/isleOfWight/crossSolent/crossSolentPro i/IsleofWightWater.asp

Jones, R.L. and Keen, D H. 1993. Pleistocene environments of the British Isles. Chapman \& Hall, London.

Leyland, J. And Darby, S.E. 2008. An empirical - conceptual gully evolution model for channelled sea cliffs. Geomorphology, 102, Issues 3-4, pp419-434.

Lott, G.K. 2010. Local stone in the buildings of the Isle of Wight. Proceedings of the Geologists' Association. Submitted for review.

McDowell, P.W., Coulton, J., Edmonds, C.N. and Poulsom, A.J. 2008. The nature, formation and engineering significance of sinkholes related to dissolution of chalk in SE Hampshire, England. In Quarterly Journal of Engineering Geology and Hydrogeology, 41, 279-290.

McEvoy, F.M, Bloodworth, A.J, Cameron, D.G, Bartlett E.L., Hobbs S.F., Spencer, N.A. Evans D.J. and Lott, G.K. 2002. Mineral resource information in support of national, regional and local planning: Isle of Wight: British Geological Survey Report CR/02/130N 
Preece, R.C. 2009. Late-glacial slope deposits at Watcombe Bottom near Ventnor. In: Briant, RM, Bates, MR, Hosfield, RT and Wenban-Smith, FF. (eds) The Quaternary of the Solent Basin and West Sussex raised beaches; Field Guide. Quaternary Research Association. pp138-144.

Rushton, N. 2005. The National Trust West Wight Estate: The Needles, West High Down, Tennyson Down and Headon Warren in Freshwater, Isle of Wight. An Archaeological and Historical Survey. Vol 2: Archaeological Inventory, Wessex Archaeology.

Wenban-Smith, F.F., Bates, M.R., Bridgland, D.R., Marshall, G.D., and Schwenninger, J.L. 2009. The Pleistocene sequence at Priory Bay, Isle of Wight (SZ635 900). In: Briant, RM, Bates, MR, Hosfield, RT and Wenban-Smith, FF. (eds) The Quaternary of the Solent Basin and West Sussex raised beaches; Field Guide. Quaternary Research Association. pp123-137.

\section{List of Figures}

Fig. 1: Digital Terrain Model (DTM) Surface model hillshade of the Isle of Wight (IPR/128-10 CT (C) UKP / Getmapping Licence No. UKP2006/01)

Fig. 2: The three divisions of landscape domains across the island (based on the bedrock geology).

Fig. 3: Landscape Domain 4: generalised map of the Quaternary deposits of the Isle of Wight

Fig. 4: Natural cast in Wealden sandstone of a dinosaur footprint found near Hanover Point

Fig. 5: Mineral extraction sites on the Isle of Wight $-a$. Working status, b. Commodity extracted c. End uses. (Source: BGS Britpits database)

Fig. 6: Evidence of coastal erosion causing landsliding near Hanover Point

\section{List of Tables}

Table 1: Stratigraphic bedrock units encountered on the IOW 
Table 1: The principal units within the bedrock encountered on the Isle of Wight

\begin{tabular}{|c|c|c|c|c|}
\hline Series & Group & \multicolumn{2}{|l|}{ Formation } & Domain Group \\
\hline \multirow{11}{*}{$\begin{array}{l}\frac{0}{\pi} \\
\stackrel{0}{0} \\
00 \\
0 \\
\frac{\pi}{\pi} \\
0\end{array}$} & \multirow[t]{3}{*}{ Solent } & \multicolumn{2}{|l|}{ Bouldnor } & \multirow{11}{*}{$\begin{array}{l}\text { Domain } 3 \text { - } \\
\text { The Northern } \\
\text { Landscape }\end{array}$} \\
\hline & & \multicolumn{2}{|c|}{ Bembridge Limestone } & \\
\hline & & \multicolumn{2}{|l|}{ Headon Hill } & \\
\hline & \multirow[t]{3}{*}{ Barton } & \multicolumn{2}{|l|}{ Becton Sand } & \\
\hline & & \multicolumn{2}{|l|}{ Barton Clay } & \\
\hline & & \multicolumn{2}{|c|}{ Boscombe Sands } & \\
\hline & \multirow{3}{*}{ Bracklesham } & WEST & FAST & \\
\hline & & Branscombe & Selsey Sand & \\
\hline & & Poole & $\begin{array}{l}\text { Marsh Farm } \\
\text { Earnley Sand } \\
\text { Wittering }\end{array}$ & \\
\hline & Thames & \multicolumn{2}{|l|}{ London Clay } & \\
\hline & Lambeth & \multicolumn{2}{|l|}{ Reading } & \\
\hline \multicolumn{4}{|c|}{ Unconformity } & \multirow{12}{*}{$\begin{array}{l}\text { Domain } 2- \\
\text { The Chalk } \\
\text { Downlands and } \\
\text { foothills }\end{array}$} \\
\hline \multirow{9}{*}{ 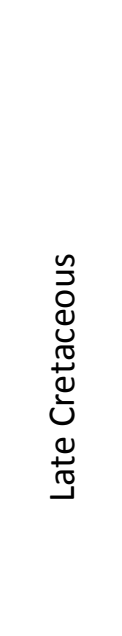 } & \multirow{7}{*}{$\begin{array}{l}\text { White } \\
\text { Chalk } \\
\text { Subgroup }\end{array}$} & \multicolumn{2}{|c|}{ Portsdown Chalk } & \\
\hline & & \multicolumn{2}{|l|}{ Culver Chalk } & \\
\hline & & \multicolumn{2}{|c|}{ Newhaven Chalk } & \\
\hline & & \multicolumn{2}{|l|}{ Seaford Chalk } & \\
\hline & & \multicolumn{2}{|c|}{ Lewes Nodular Chalk } & \\
\hline & & \multicolumn{2}{|l|}{ New Pit Chalk } & \\
\hline & & \multicolumn{2}{|c|}{ Holywell Nodular Chalk } & \\
\hline & \multirow{2}{*}{$\begin{array}{l}\text { Grey } \\
\text { Chalk } \\
\text { Subgroup }\end{array}$} & \multicolumn{2}{|l|}{ Zig Zag Chalk } & \\
\hline & & West Melbur & lalk & \\
\hline & Selbourne & Upper Green & & \\
\hline & & Gault & & \\
\hline & Lower & Carstone/Mc & andstone & Domain 1 - \\
\hline$\underset{\widetilde{J}}{\mathscr{J}}$ & Greensand & Sandrock & & The Lower \\
\hline บั & & Ferruginous & & Cretaceous \\
\hline 产 & & Atherfield $\mathrm{Cl}$ & & \\
\hline & Wealden & Vectis & & \\
\hline & & Wessex & & \\
\hline
\end{tabular}




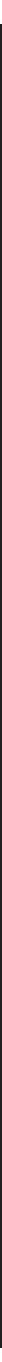

Figure 1

Figure 1 
Figure 2

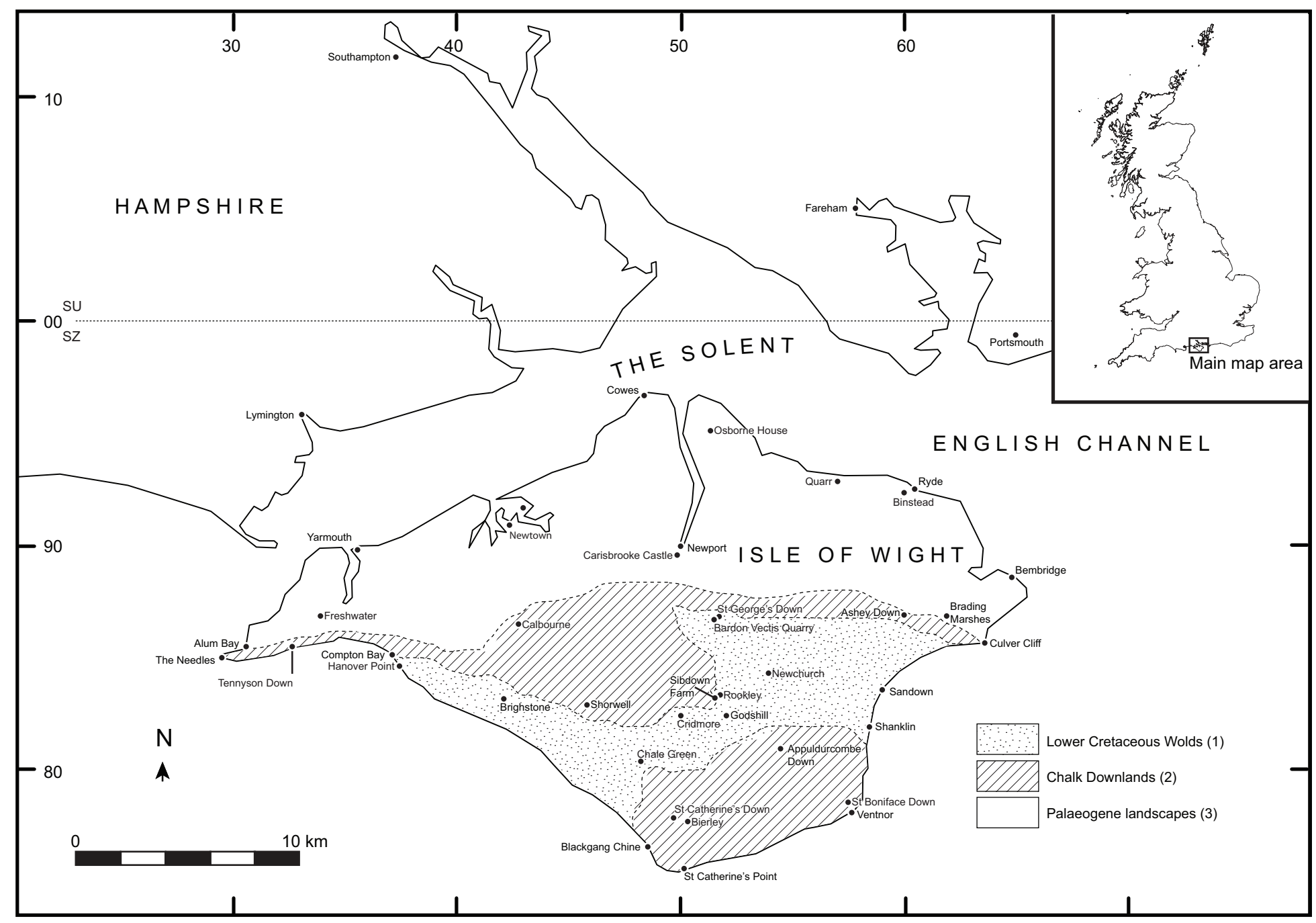

FIGURE 2 


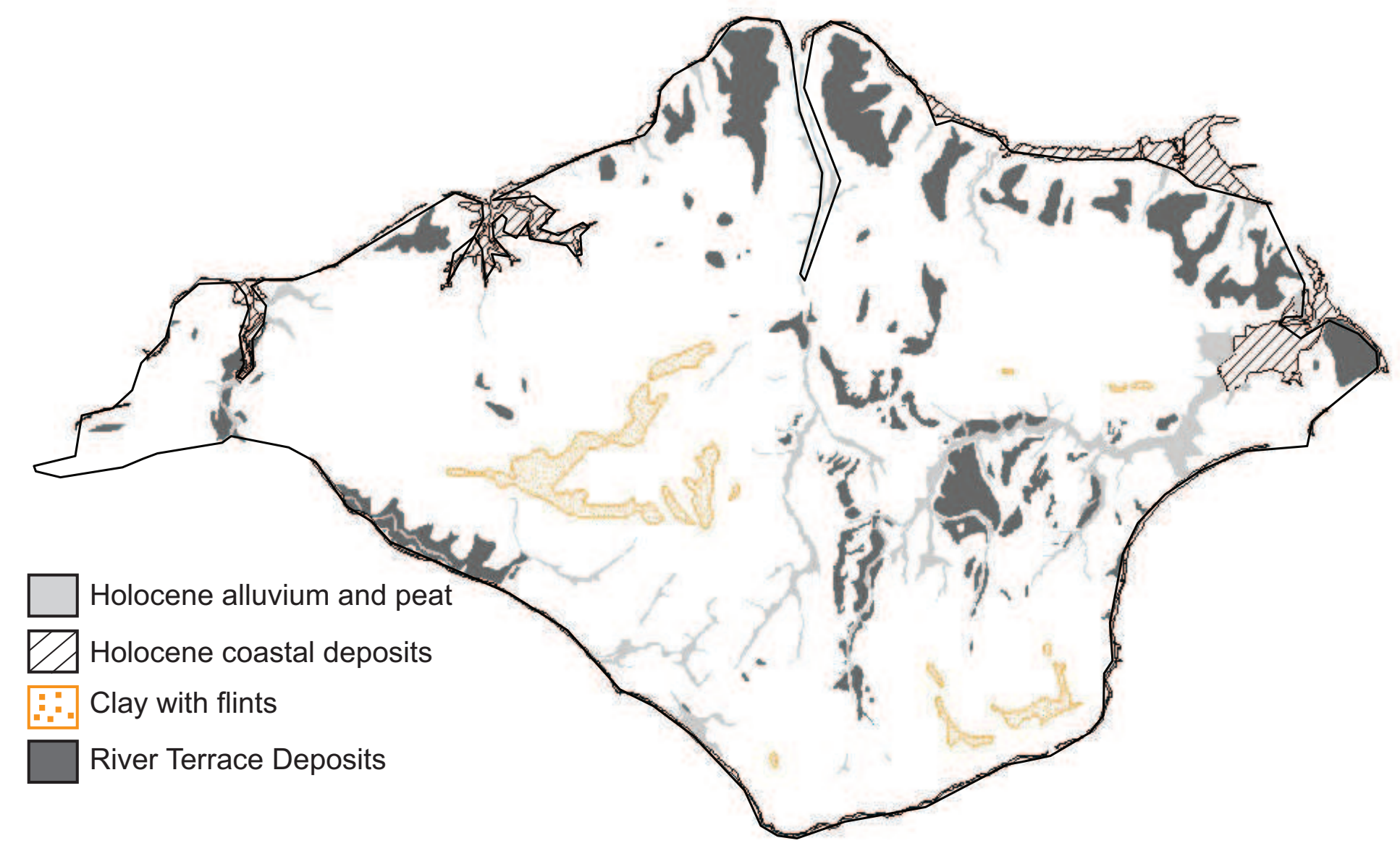

Figure 3

Figure 3 


\section{Click here to download high resolution image

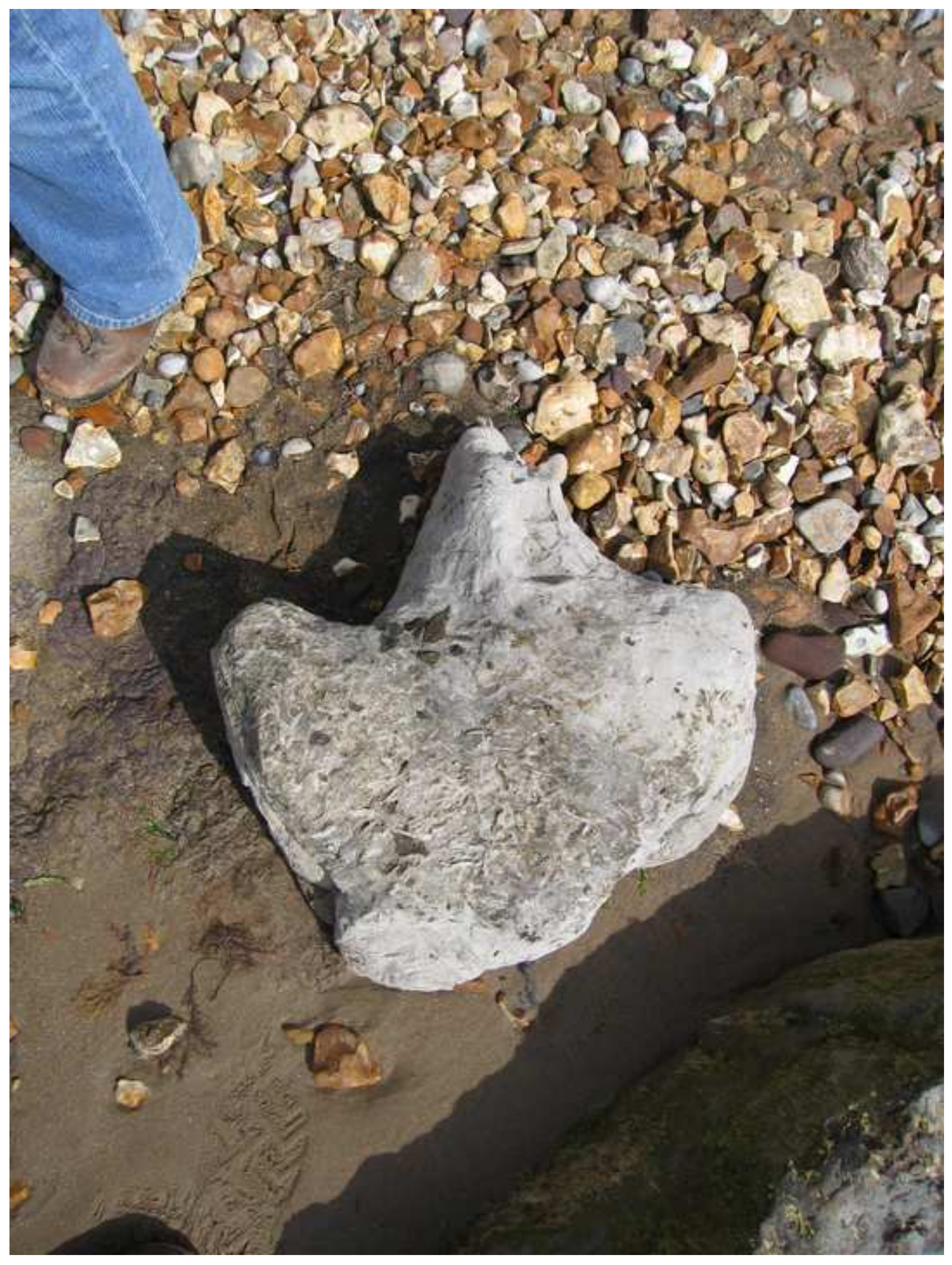

Figure 4 .

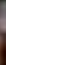

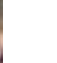

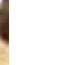

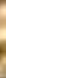
.

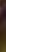
. .

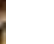

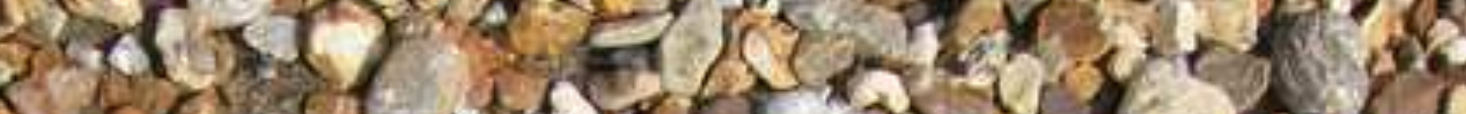

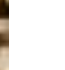

.



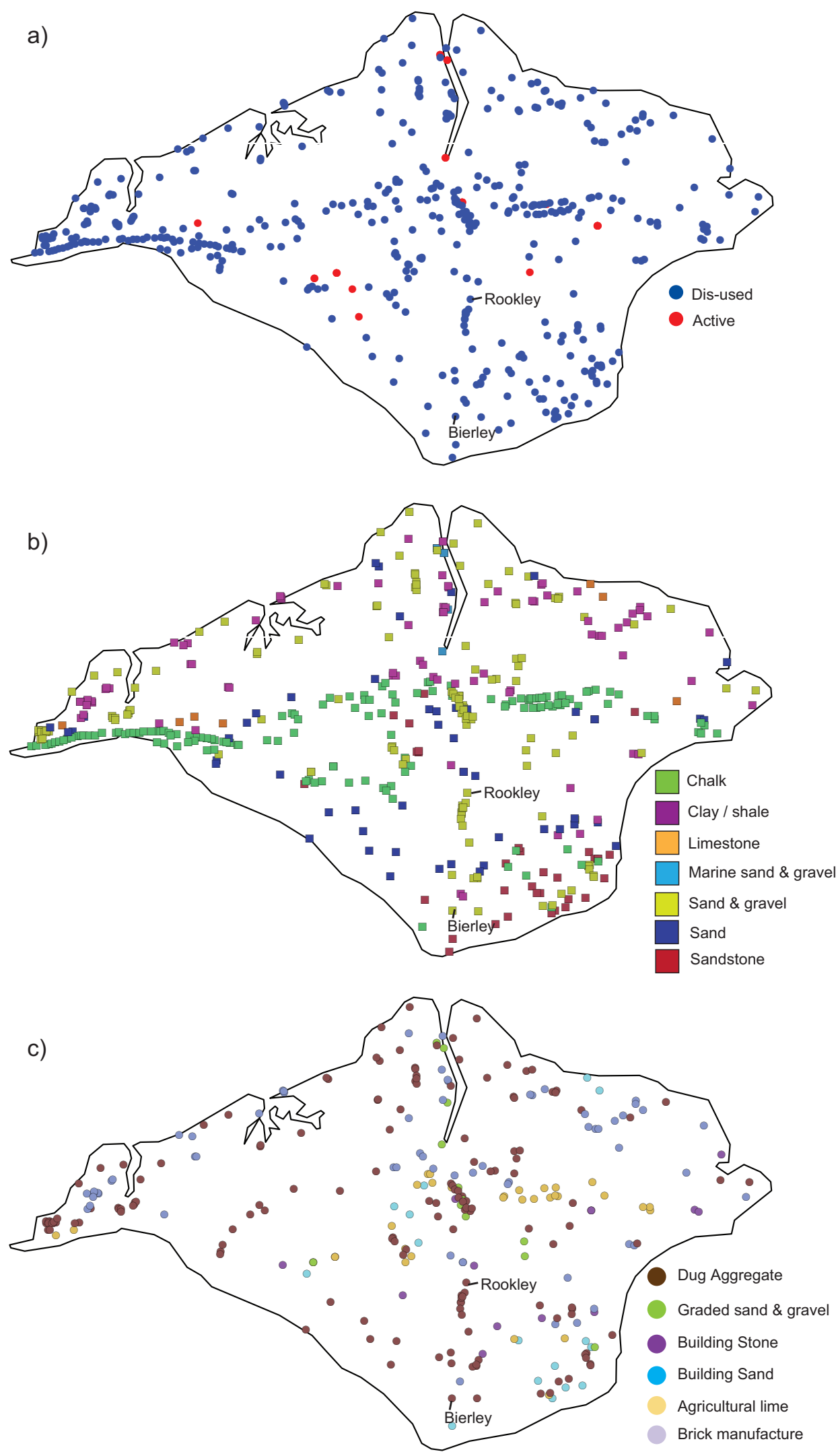

Figure 5 
Click here to download high resolution image

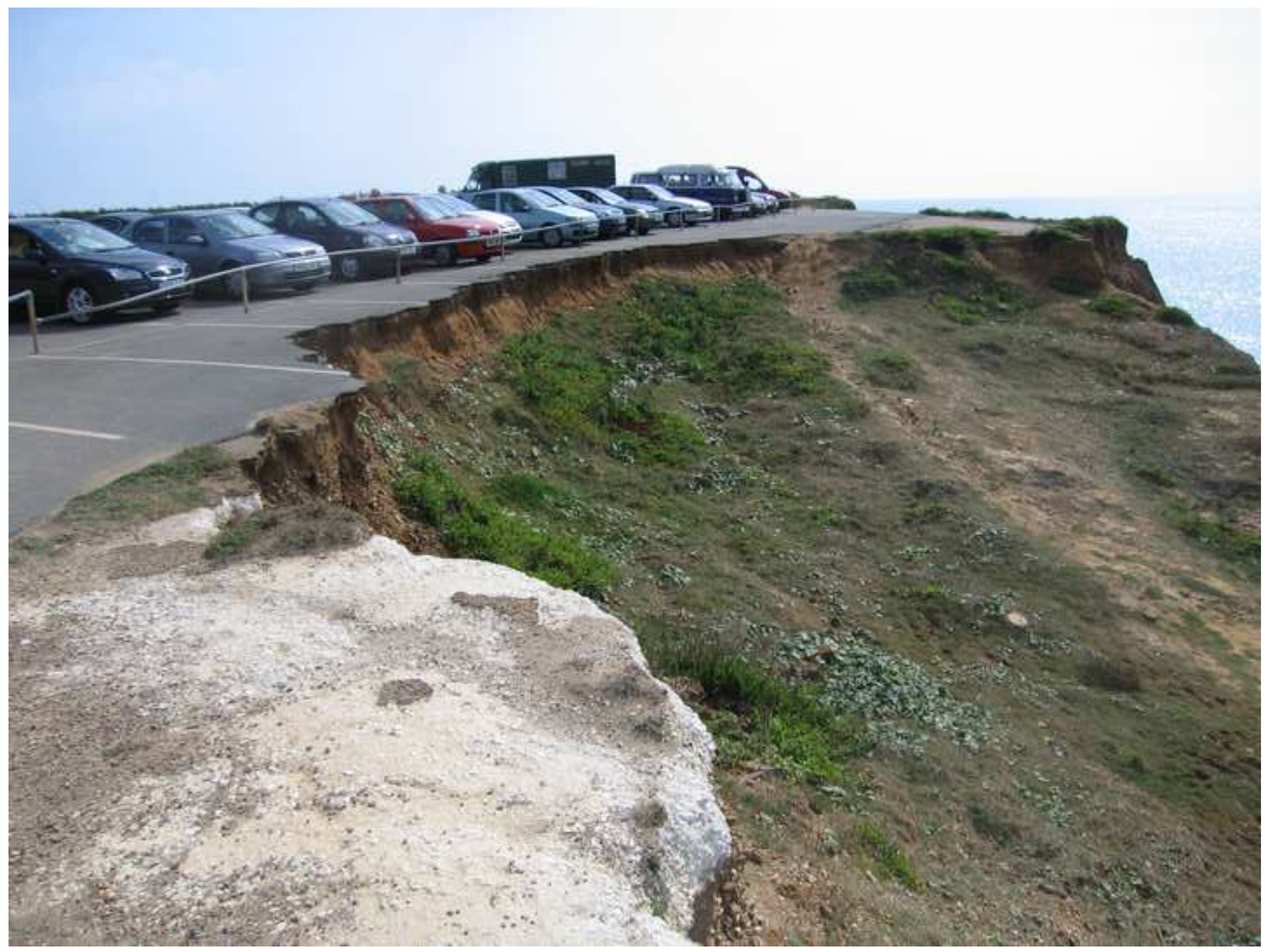

